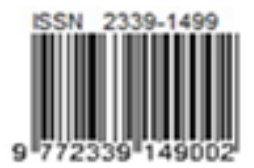

\title{
Analisis Kelayakan Aspek Teknis Industri Pengolahan Biofarmaka Berbahan Baku Bawang Tiwai
}

\author{
Muhammad Ilham Ramadhan ${ }^{1}$, Muriani Emelda Isharyani' ${ }^{2}$ Farida Djumiati Sitania ${ }^{3}$ \\ 1,2,3 Fakultas Teknik, Teknik Industri, Universitas Mulawarman \\ Alamat: Kampus Gn. Kelua, JI. Sambaliung Nomor 9 Samarinda 75119 \\ Email:1ilhamramadhan7296@yahoo.co.id, ${ }^{2}$ dekan@ftunmul.ac.id, ${ }^{3}$ farida@gmail.com
}

\begin{abstract}
Tiwai onion is one of species of flowering and bulbous plants in Borneo forest that can be developed as biopharmaceutical source for industrial scale. Industrial development of tiwai processing into a tea bag product in UKM Solaindo has many technical constraints. Therefore, it is necessary to conduct a research which aims to overcome the technical constraints, so that tiwai onion product into a tea bag in UKM Solaindo could get increased to fulfill the market needs and also to become a competitive local product. The technical aspects include determining a factory location, production capacity, machinery and equipment, and factory facility layout. Determining a factory location using ranking procedure determined Tenggarong as the best location to establish an industrial factory of tiwai onion with the total score of 15.90. Production capacity is conducted by demand forecasting using weighted moving average method, and forecasting value obtained is 618 units/month. Machinery and equipment used for production process from the factory that will be set up in every process are tray, automatic sealer machine, washing machine, oven, chopping machine, stamping equipment, and sealer machine. The most appropriate scoring systems for factory facility layout are ARC, ARD, SRD, and AAD that have 10 facilities such as administration room of $80 \mathrm{~m}^{2}$, production facilities $37,5 \mathrm{~m}^{2}$, shipping facilities $7,5 \mathrm{~m}^{2}$, material warehouse $15 \mathrm{~m}^{2}$, finished product warehouse $17,5 \mathrm{~m}^{2}$, reception facilities $7,5 \mathrm{~m}^{2}$, and quality control facilities $12 \mathrm{~m}^{2}$.
\end{abstract}

Keywords: Factory layout, machine, production capacity, ranking Procedure, tiwai onions

\section{Abstrak}

Bawang tiwai merupakan spesies tumbuhan berbunga dan berumbi di hutan Kalimantan yang dapat berpotensi menjadi bahan baku biofarmaka pada skala industri. Perkembangan industri pengolahan bawang tiwai menjadi produk teh celup di UKM Solaindo masih menemui beberapa kendala teknis, oleh sebab itu diperlukan penelitian untuk mengatasi kendala teknis dan produksi yang dihadapi, sehingga produk olahan bawang tiwai menjadi produk teh celup di UKM Solaindo dapat meningkat untuk memenuhi kebutuhan pasar serta menjadi produk lokal unggulan yang berdaya saing tinggi. Aspek teknis yang diteliti meliputi penentuan lokasi pabrik, kapasitas produksi, mesin dan peralatan, dan tata letak fasilitas pabrik. Penentuan lokasi pabrik dengan menggunakan ranking procedure menetapkan bahwa Tenggarong merupakan lokasi terbaik pendirian pabrik industri pengolahan teh bawang tiwai dengan total skor 15,90. Kapasitas produksi dilakukan dengan peramalan permintaan menggunakan metode weighted moving average, diperoleh nilai peramalan sebesar 618 unit/bulan. Mesin dan peralatan yang digunakan untuk proses produksi dari pabrik yang akan didirikan disetiap prosesnya yaitu loyang, mesin sealer otomatis, mesin pencuci, oven, mesin rajang, alat stamp, mesin sealer. Tata letak fasilitas pabrik yang dianggap paling tepat dengan sistem penilaian ARC, ARD, SRD dan AAD memiliki 10 fasilitas yakni ruang administrasi dengan luas $80 \mathrm{~m}^{2}$, fasilitas produksi $37,5 \mathrm{~m}^{2}$, pengiriman $7,5 \mathrm{~m}^{2}$, gudang bahan $15 \mathrm{~m}^{2}$, gudang produk jadi $17,5 \mathrm{~m}^{2}$, penerimaan $7,5 \mathrm{~m}^{2}$, dan fasilitas pengendalian mutu $12 \mathrm{~m}^{2}$.

Kata Kunci: Bawang Tiwai, Kapasitas Produksi, Mesin, Ranking Procedure, Tata Letak Pabrik 


\section{Pendahuluan}

Bawang tiwai merupakan tanaman yang memiliki nama latin Eleutherina American L. Merr salah satu species tumbuhan berbunga dan berumbi di hutan Kalimantan. Bawang tiwai biasa digunakan oleh masyarakat pedalaman menjadi obat ramuan tradisional, untuk mengatasi berbagai penyakit degeneratif, dan kronis. Tanaman ini memiliki warna umbi merah dengan daun hijau berbentuk pita dan bunganya berwarna putih. Dalam umbi bawang tiwai terkandung berbagai macam senyawa yang diketahui berkhasiat untuk mengatasi berbagai masalah kesehatan. Secara empiris bawang tiwai sudah dipergunakan masyarakat lokal sebagai obat berbagai jenis penyakit ringan maupun berat seperti kanker payudara, obat penurun darah tinggi (hipertensi) dan penyakit kencing manis (diabetes militus). Bawang tiwai dapat dikembangkan sebagai sumber biofarmaka untuk skala industri. Tanaman ini dapat tumbuh dan beradaptasi di semua iklim dan jenis tanah, dengan waktu panen relatif singkat yakni 3-4 bulan sehingga mudah dikembangkan dalam skala besar.

Berdasarkan hasil wawancara dengan bapak Kalif selaku pemilik UKM Solaindo, tradisi minum teh merupakan suatu kebiasaan yang menjadi ciri khas masyarakat Indonesia yang terdiri dari berbagai suku bangsa. Teh sangat digemari oleh semua lapisan masyarakat, baik orang tua maupun muda. Produk minuman berbahan baku bawang tiwai adalah salah satu produk yang mengemas manfaat tanaman bawang tiwai dalam bentuk teh celup. Kelebihan produk ini diiringi semakin meningkatnya peluang produk sehat di pasaran menjadikan usaha teh bawang tiwai berpotensial untuk dikembangkan lebih lanjut. Berdasarkan data penjualan pada bulan November 2017 hingga Februari 2018, jumlah permintaan terhadap produk teh bawang tiwai mengalami peningkatan, dengan rata-rata peningkatan $1,76 \%$. Dalam memproduksi teh bawang tiwai UKM Solaindo mampu memproduksi rata-rata $58,68 \mathrm{Kg}$ bawang tiwai dalam sebulan karena tingginya permintaan. Potensi pasar produk teh bawang tiwai masih sangat besar. Namun, dengan besarnya potensi pasar produk teh bawang tiwai masih banyak terdapat kendala, seperti tingginya permintaan pasar yang tidak sebanding dengan kapasitas produksinya dan ketersediaan bahan baku, rendahnya mutu bahan baku akibat teknik budidaya dan penanganan pasca panen yang keliru, kurangnya dukungan dari pihak pemerintah dalam hal permodalan dan pelatihan, serta keterbatasan teknologi dan infrastruktur dalam pengolahan bawang tiwai.

Berdasarkan hal tersebut, maka usaha pengolahan teh bawang tiwai di UKM Solaindo tidak akan berkembang jika masih diproduksi dan dipasarkan secara sederhana akibat keterbatasan teknologi dan infrastruktur dalam pengolahan bawang tiwai yaitu oleh industri rumahan. Untuk itu diperlukan analisis kelayakan teknis pengolahan teh bawang tiwai untuk skala industri pabrik. Analisis teknis dilakukan untuk mengetahui lokasi pabrik, menghitung kapasitas produksi yang dianggap paling optimal, menentukan teknologi mesin, dan perancangan tata letak fasilitas pabrik yang tepat. Dengan begitu diharapkan produk olahan bawang tiwai menjadi produk teh di UKM Solaindo dapat semakin besar dan meningkat untuk memenuhi kebutuhan pasar serta menjadi produk lokal unggulan yang berdaya saing tinggi.

Penelitian ini akan menganalisis kelayakan teknis untuk menilai kesiapan UKM Solaindo dalam menjalankan usahanya dengan menilai ketepatan lokasi pabrik, kapasitas produksi dari pabrik yang akan didirikan, teknologi mesin yang digunakan untuk proses produksi, dan perancangan tata letak fasilitas dari pabrik yang dianggap paling tepat.

\section{Metode Penelitian}

\section{Penentuan lokasi berdasarkan metode kualitatif (ranking procedure)}

Menurut Wignjosoebroto (2009), metode ini lebih bersifat kualitatif dan subjektif. Dengan menggunakan metode ini akan baik aplikasinya untuk problema-problema yang sulit untuk dikuantifikasikan.

Prosedur yang harus dilakukan dalam pendekatan dengan metode kualitatif ini bisa diatur berdasarkan langkah-langkah analisa sebagai berikut Wignjosoebroto (2009):

1. Langkah pertama adalah mengidentifikasikan faktor-faktor yang relevan dan memiliki signifikasi yang berkaitan dengan proses pemilihan lokasi pabrik yang akan ditentukan oleh pelaku usaha teh bawang tiwai, seperti halnya dengan faktor-faktor berikut:

a. Lokasi pensuplai bahan baku,

b. Lokasi pemasaran, 
c. Lokasi tenaga kerja,

d. Kondisi iklim,

e. UU dan peraturan lainnya, dan

f. Factory utilities dan services.

2. Langkah kedua adalah pemberian bobot dari masing-masing faktor yang telah diidentifikasikan tersebut berdasarkan derajat kepentingannya (weighted procedure) yang telah ditentukan oleh pelaku usaha teh bawang tiwai, sebagai contoh dengan cara sebagai berikut:

a. Lokasi pensuplai bahan baku $20 \%$ bobotnya $\left(\mathrm{X}_{1}\right)$,

b. Lokasi pemasaran $40 \%\left(X_{2}\right)$,

c. Lokasi tenaga kerja $\left(\mathrm{X}_{3}\right)$,

d. Kondisi iklim $5 \%\left(X_{4}\right)$,

e. UU dan peraturan-peraturan daerah setempat $5 \%\left(X_{5}\right)$, dan

f. Factory utilities dan services $20 \%\left(X_{6}\right)$.

3. Langkah ketiga adalah memberi skor (nilai) untuk masing-masing faktor yang diidentifikasikan sesuai dengan skala angka (range berkisar $0 \mathrm{~s} / \mathrm{d} 10$, dengan 10 terbaik) dari masing-masing alternatif lokasi yang dianalisa sesuai dengan alternatif lokasi sesuai matriks skor dari setiap faktor dan alternatif lokasi yang akan diisi oleh pelaku usaha, dan

4. Langkah keempat dari prosedur ini adalah dengan mengalikan bobot dari masingmasing faktor dengan skor tiap-tiap alternatif yang ada dan menghitung total perkalian antara skor dan bobot. Dari hasil total perkalian maka pemilihan lokasi dianggap paling baik apabila memiliki nilai alternatif lokasi terbesar.

\section{Perhitungan kapasitas produksi}

Dalam perhitungan besarnya kapasitas produksi yang dibutuhkan dengan melihat permintaan yang pada masa depan dilakukan melalui proses peramalan pasar. Alat untuk meramalkan besarnya pasar dilakukan dengan berbagai metode peramalan, mulai dari yang sederhana sampai kepada yang paling komplek (Kusuma, 2009). Penggunaan alat peramalan akan sangat bergantung dengan jenis data informasi yang terkumpul serta obyektif dari peramalan tersebut. Pada penentuan kapasitas produksi UKM Solaindo ini dilakukan dengan peramalan permintaan pasar dengan menggunakan software WinQSB dengan metode moving average, weighted moving average, dan single exponential smoothing.
Secara garis besar, tahap-tahap yang dilakukan dalam proses peramalan sebagai berikut yaitu tahap mengumpulkan data, tahap mengolah data (tabulasi data untuk memahami pola data), penentuan metode peramalan yang cocok dengan mempertimbangkan horizon waktu, pola data, jenis peramalan, kemudahan dan ketepatan, dalam proses penggunaannya.

Tahap berikutnya adalah memproyeksikan data dengan pertimbangan faktor perubahan yang ada untuk beberapa periode, dan yang terakhir adalah tahap pengambilan keputusan.

Hasil peramalan yang telah dilakukan digunakan untuk mengambil keputusan dalam membuat perencanaan kapasitas produksi.

\section{Penentuan jenis teknologi mesin}

Pemilihan mesin, peralatan, dan teknologi merupakan hal yang penting. Ketepatan jenis teknologi mesin yang akan digunakan pada produksi teh bawang tiwai akan dianalisis menggunakan peta proses operasi atau dikenal dengan operations process chart dapat menunjukkan tahap-tahap kronologis dari semua proses operasi inspeksi, besarnya waktu longgar, dan jumlah bahan baku yang digunakan di dalam suatu proses manufacturing yaitu sejak datangnya bahan baku sampai ke tahapan terakhir yaitu pembungkusan (packaging) dari produk jadi yang dihasilkan. Peta ini melukiskan peta operasi dari seluruh komponen-komponen dan subassemblies sampai menuju main assembly.

\section{Perhitungan tata letak pabrik}

Layout merupakan suatu proses dalam penentuan bentuk dan penempatan fasilitas yang dapat menentukan efisiensi produksi/operasi. Layout dirancang berkenaan dengan produk, proses, sumber daya manusia, dan lokasi sehingga dapat tercapai efisiensi operasi.

Penentuan tata letak pabrik yang diperlukan dilakukan dengan menggunakan metode Activity Relationship Chart (ARC), metode Activity Relationship Diagram (ARD), Space Relationship Diagram (SRD) dan metode Area Allocating Diagram (AAD).

\section{Hasil dan Pembahasan}

Hasil dari data yang telah diperoleh selanjutnya dapat dilakukan pengolahan yakni terdiri dari penentuan lokasi usaha, rencana 
kapasitas produksi, mesin/teknologi yang akan digunakan, dan pembuatan layout pabrik.

\section{Penentuan Lokasi Pabrik}

Berdasarkan data yang telah didapatkan dalam penentuan lokasi pabrik industri pengolahan bawang tiwai menjadi produk teh celup, adapun prosedur yang harus dilaksanakan dalam pendekatan dengan metode kualitatif ini bisa diatur berdasarkan langkah-langkah analisa hasil penentuan lokasi pabrik dengan menggunakan 2 narasumber yaitu sebagai berikut: (Sugiyono, 2013)

1. Langkah pertama

Mengidentifikasi faktor-faktor yang relevan dan memiliki signifikasi yang berkaitan dengan proses pemilihan lokasi industri pengolahan bawang tiwai menjadi produk teh celup, fakto-faktor ini ditentukan menurut sumber dari Indrajit dan Permono (2005) dan Wignjosoebroto (2009). Faktor faktor dipertimbangan dalam penentuan lokasi pabrik industri pengolahan bawang tiwai menjadi produk teh tiwai adalah:

a. Kedekatan dengan pasar,

b. Kedekatan dengan bahan baku,

c. Ketersediaan sarana dan prasarana (transportasi, listrik, dan air),

d. Ketersediaan lahan untuk melakukan ekspansi,

e. Kedekatan dengan pusat pemerintahan,

f. Pengaruh iklim,

g. Tingkat upah dan ketersediaan tenaga kerja,

h. Harga dan kondisi tanah,

i. Lingkungan, dan

j. Sosial budaya masyarakat setempat.

2. Langkah kedua

Pemberian bobot dari masing-masing faktor yang telah diidentifikasi tersebut berdasarkan derajat kepentingannya (weighted procedure) dan memberi skor (nilai) untuk masing-masing faktor yang diidentifikasikan sesuai dengan skala angka (range berkisar $0 \mathrm{~s} / \mathrm{d} 10$, dengan 10 terbaik) dari masing-masing alternatif lokasi yang dianalisa.

Berikut ini adalah bobot dan nilai untuk masing-masing faktor yang telah ditentukan oleh UKM Solaindo dan Dinas Perindagkop dapat dilihat pada Tabel 1 sebagai berikut:
Tabel 1. Penentuan nilai skor

\begin{tabular}{|c|l|c|c|c|c|c|c|}
\hline \multirow{2}{*}{ No } & \multirow{2}{*}{ Kriteria Penilaian } & \multicolumn{3}{|c|}{ UKM } & \multicolumn{4}{|c|}{ Dinas } \\
\cline { 3 - 8 } & Solaindo & \multicolumn{3}{c|}{ Perindagkop } \\
\hline 1 & $\begin{array}{l}\text { Kedekatan dengan } \\
\text { pasar }\end{array}$ & 5 & 7 & 9 & 15 & 5 & 9 \\
\hline 2 & $\begin{array}{l}\text { Kedekatan dengan } \\
\text { bahan baku }\end{array}$ & 20 & 1 & 2 & 20 & 9 & 4 \\
\hline 3 & $\begin{array}{l}\text { Ketersediaan saran } \\
\text { dan prasarana }\end{array}$ & 5 & 7 & 8 & 15 & 6 & 8 \\
\hline 4 & $\begin{array}{l}\text { Ketersediaan lahan } \\
\text { untuk melakukan } \\
\text { ekspansi }\end{array}$ & 10 & 7 & 1 & 10 & 8 & 3 \\
\hline 5 & $\begin{array}{l}\text { Kedekatan dengan } \\
\text { pusat } \\
\text { pemerintahan }\end{array}$ & 5 & 7 & 8 & 5 & 5 & 8 \\
\hline 6 & $\begin{array}{l}\text { Pengaruh iklim } \\
7\end{array}$ & 5 & 7 & 3 & 5 & 6 & 5 \\
\hline $\begin{array}{l}\text { Tingkat upah dan } \\
\text { ketersediaan } \\
\text { tenaga kerja }\end{array}$ & 15 & 1 & 5 & 10 & 7 & 5 \\
\hline 8 & $\begin{array}{l}\text { Harga dan kondisi } \\
\text { tanah }\end{array}$ & 20 & 1 & 3 & 10 & 8 & 6 \\
\hline 9 & Lingkungan & 5 & 8 & 4 & 5 & 7 & 4 \\
\hline 10 & $\begin{array}{l}\text { Sosial budaya } \\
\text { masyarakat } \\
\text { setempat }\end{array}$ & 10 & 9 & 5 & 5 & 7 & 5 \\
\hline
\end{tabular}

Keterangan: $\%=$ Bobot, $\mathrm{T}=$ Tenggarong,

$$
\mathrm{S}=\text { Samarinda }
$$

3. Langkah ketiga

Mengalikan bobot dari masing-masing faktor dengan skor tiap-tiap alternatif yang ada dan menghitung total perkalian antara skor dan bobot. Dari hasil total perkalian maka pemilihan lokasi dianggap paling baik apabila memiliki nilai alternatif lokasi terbesar. Hasil tersebut dapat dilihat pada Tabel 2 sebagai berikut:

Tabel 2. Matriks Penilaian Lokasi Pabrik

\begin{tabular}{|c|c|c|c|c|c|}
\hline \multirow[t]{2}{*}{ No } & \multirow{2}{*}{$\begin{array}{l}\text { Kriteria } \\
\text { Penilaian }\end{array}$} & \multicolumn{2}{|c|}{$\begin{array}{c}\text { UKM } \\
\text { Solaindo }\end{array}$} & \multicolumn{2}{|c|}{$\begin{array}{c}\text { Dinas } \\
\text { Perindagkop }\end{array}$} \\
\hline & & $\begin{array}{c}T \\
T\end{array}$ & $\mathrm{~S}$ & $T$ & $\mathrm{~S}$ \\
\hline 1 & $\begin{array}{l}\text { Kedekatan } \\
\text { dengan pasar }\end{array}$ & 0,35 & 0,45 & 0,75 & 1,35 \\
\hline 2 & $\begin{array}{l}\text { Kedekatan } \\
\text { dengan bahan } \\
\text { baku }\end{array}$ & 2,00 & 0,40 & 1,80 & 0,80 \\
\hline 3 & $\begin{array}{l}\text { Ketersediaan } \\
\text { sarana dan } \\
\text { prasarana }\end{array}$ & 0,35 & 0,40 & 0,90 & 1,20 \\
\hline 4 & $\begin{array}{l}\text { Ketersediaaan } \\
\text { lahan untuk } \\
\text { melakukan } \\
\text { ekspansi }\end{array}$ & 0,70 & 0,10 & 0,80 & 0,30 \\
\hline 5 & $\begin{array}{l}\text { Kedekatan } \\
\text { dengan pusat } \\
\text { pemerintahan }\end{array}$ & 0,35 & 0,40 & 0,25 & 0,40 \\
\hline 6 & Pengaruh iklim & 0,35 & 0,15 & 0,30 & 0,25 \\
\hline 7 & $\begin{array}{l}\text { Tingkat upah } \\
\text { dan } \\
\text { ketersediaan } \\
\text { tenaga kerja }\end{array}$ & 1,50 & 0,75 & 0,70 & 0,50 \\
\hline 8 & $\begin{array}{l}\text { Harga dan } \\
\text { kondisi tanah }\end{array}$ & 2,00 & 0,60 & 0,80 & 0,60 \\
\hline 9 & Lingkungan & 0,40 & 0,20 & 0,35 & 0,20 \\
\hline 10 & $\begin{array}{l}\text { Sosial budaya } \\
\text { masyarakat } \\
\text { setempat }\end{array}$ & 0,90 & 0,50 & 0,35 & 0,25 \\
\hline & Total & 8,90 & 3,95 & 7,00 & 5,85 \\
\hline
\end{tabular}


Dari hasil perhitungan yang telah didapatkan menurut pemilik UKM Solaindo dan Dinas Perindagkop maka jumlah bobot skor untuk masing-masing wilayah adalah Tenggarong sebesar 15,90 dan Samarinda sebesar 9,80. Berdasarkan hasil perhitungan total matriks pemilihan lokasi untuk setiap lokasi alternatif maka lokasi yang terpilih sebagai lokasi pabrik yaitu Tenggarong.

\section{Kapasitas Produksi}

Data permintaan untuk teh bawang tiwai dimulai dari bulan November 2017 s/d April 2018 dapat dilihat pada Tabel 3 sebagai berikut:

Tabel 3. Data permintaan

\begin{tabular}{|l|c|}
\hline \multicolumn{1}{|c|}{ Bulan } & Data permintaan (unit) \\
\hline November 2017 & 43 \\
\hline Desember 2017 & 167 \\
\hline Januari 2018 & 1225 \\
\hline Februari 2018 & 590 \\
\hline Maret 2018 & 588 \\
\hline April 2018 & 647 \\
\hline
\end{tabular}

Dari pengamatan data jumlah produksi teh bawang tiwai untuk meramalkan permintaan 12 bulan kedepan yaitu Mei 2018 hingga April 2019 dengan menggunakan data series dalam rentang waktu 6 bulan terakhir periode bulan November 2017 sampai dengan bulan April 2018 sejumlah 6 data aktual. Dari deret waktu jumlah permintaan teh bawang tiwai tersebut akan menggambarkan pola data yang membantu menentukan pemilihan model peramalan yang tepat agar mendekati data aktualnya. Pola data aktual dianalisa menggunakan program microsoft exel 2016 dan software minitab 17 untuk mengetahui unsurunsur yang terdapat pada data jumlah produksi karet apakah terdapat data stasioner memiliki unsur musiman dan unsur trend yaitu dengan mengamati pola data permintaan teh bawang tiwai, plot Autoccorelation Function (ACF), hal ini sesuai dengan Firdaus (2006) dalam Tohir (2011) yang menyatakan bahwa ACF dapat digunakan untuk mengidentifikasi apakah data itu trend, stasioner, variasi musiman dan siklus. Pola data permintaan teh bawang tiwai dan grafik autocorrelation function dapat dilihat pada Gambar 1 dan Gambar 2 sebagai berikut:

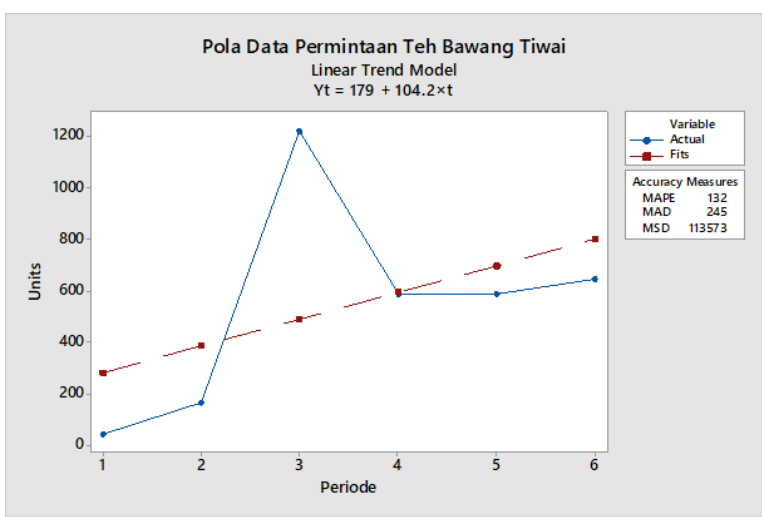

Gambar 1. Pola data permintaan

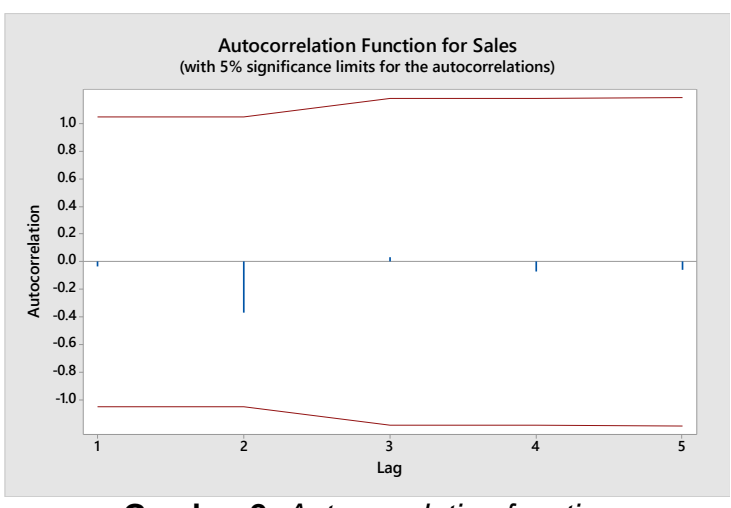

Gambar 2. Autocorrelation function

Berdasarkan hasil pengamatan pola series plot pada Gambar 4.2 pola data permintaan mengandung pola trend naik. Dari grafik plot permintaan yang terbentuk maka pola data permintaan teh bawang tiwai berbentuk trend, unsur trend dapat terlihat dari awal periode sampai akhir periode yang cenderung menunjukkan pergerakan naik pada tiap periode bulan. Berdasarkan plot autokolerasi (ACF) yang terbentuk bersifat eksponensial yaitu dilihat dari pergerakannya yang tidak secara cepat mendekati nol yang menunjukkan unsur trend sesuai dengan Firdaus (2006) dalam Tohir (2011) yaitu unsur trend diketahui dengan adanya beda kala pertama tinggi dan berbeda dengan nol secara signifikan, lalu turun mendekati nol saat series meningkat. Berdasarkan grafik pola data dan pergerakan grafik ACF dapat disimpulkan bahwa pola data permintaan teh bawang tiwai berbentuk trend naik.

Peramalan dilakukan untuk mengetahui perkiraan permintaan 12 periode kedepan yakni untuk periode Mei 2018 sampai dengan April 2019 dengan menggunakan data penjualan 6 periode sebelumnya yang dimulai dari November 2017 sampai dengan April 2018. Metode peramalan yang digunakan adalah moving average, weighted moving average, 
dan single exponential smoothing. Peramalan pada produk teh bawang tiwai dilakukan dengan menggunakan software WinQSB.

\section{Moving average}

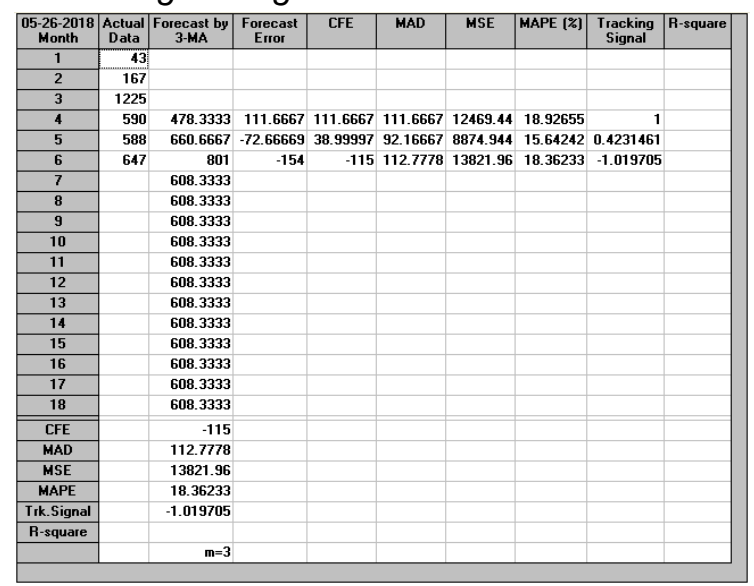

Gambar 3. Peramalan dengan metode moving average

\section{Weighted moving average}

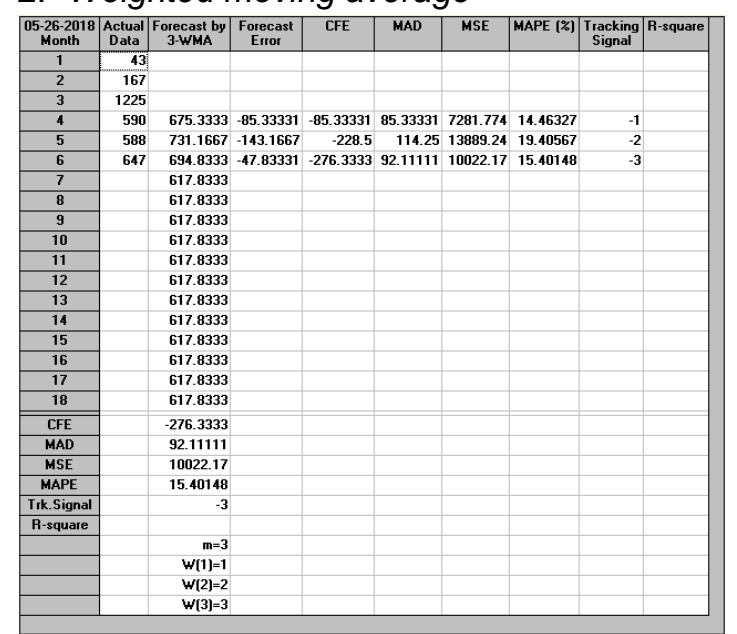

Gambar 4. Peramalan dengan metode weighted moving averaage

\section{Single exponential smoothing}

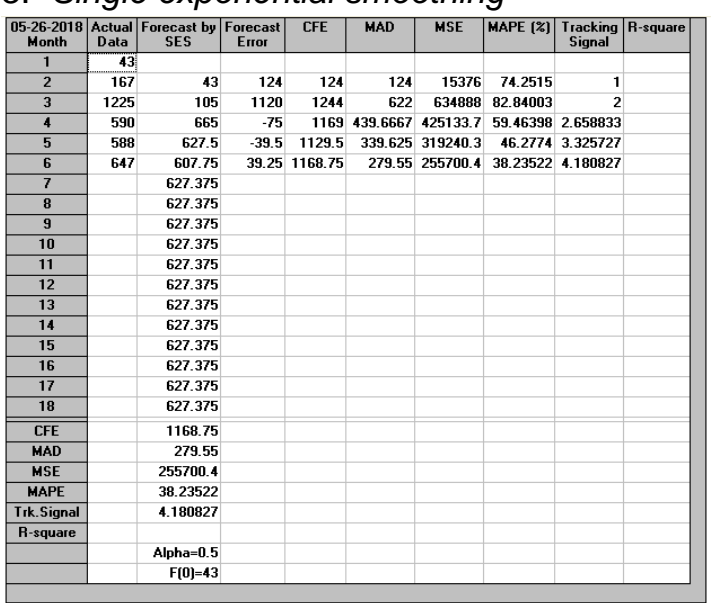

Gambar 5. Peramalan dengan metode single exponential smoothing
Setelah dilakukan peramalan pada produk teh bawang tiwai. Berdasarkan hasil peramalan dengan metode moving average, weighted moving average, dan single exponential smoothing. Didapatkan hasil verifikasi tingkat kesalahan dengan menggunakan metode mean absolute deviation (MAD), mean square error (MSE), mean absolute percentage error (MAPE), dan tracking signal (TS) dipilih yang paling banyak memiliki nilai error paling kecil ialah peramalan dengan metode weighted moving average (WMA).

Kapasitas produksi dari industri pengolahan bawang tiwai menjadi teh celup dapat dilihat pada Tabel 4.

Tabel 4. Kapasitas produksi

\begin{tabular}{|l|c|c|}
\hline Waktu & Unit & Jumlah (Kg) \\
\hline Per tahun & 7416 & 800,91 \\
\hline Per bulan & 618 & 66,74 \\
\hline
\end{tabular}

\section{Teknologi mesin dan peralatan}

Berikut ini merupakan data dari mesin dan peralatan produksi awal yang digunakan dalam proses pembuatan teh bawang tiwai (Tabel 5 dan Tabel 6).

Ta Tabel 5. Mesin dan peralatan produksi awal

\begin{tabular}{|c|c|c|c|}
\hline Jenis Alat & Spesifikasi & Gambar & Keterangan \\
\hline Loyang & $\begin{array}{l}\text { Dimensi: } 31 \\
\times 23 \times 4 \mathrm{~cm}\end{array}$ & & $\begin{array}{l}\text { Untuk tempat } \\
\text { menyimpan bawang } \\
\text { tiwai yang telah } \\
\text { dirajang }\end{array}$ \\
\hline Nampan & $\begin{array}{l}\text { Dimensi: } \\
\text { diameter } 20 \\
\mathrm{~cm}\end{array}$ & & $\begin{array}{l}\text { Untuk tempat } \\
\text { menyimpan bawang } \\
\text { tiwai yang telah } \\
\text { dikemas dengan } \\
\text { kantung celup }\end{array}$ \\
\hline Timbangan & $\begin{array}{l}\text { Kapasitas } \\
1000 \text { gram, } \\
\text { Dimensi: } 25 \\
\text { x19 cm }\end{array}$ & & $\begin{array}{l}\text { Timbangan untuk } \\
\text { menimbang bahan } \\
\text { di bawah } 1000 \text { gram }\end{array}$ \\
\hline Kompor & $\begin{array}{l}\text { Kompor } 2 \\
\text { mata }\end{array}$ & & $\begin{array}{l}\text { Alat untuk } \\
\text { memanaskan } \\
\text { bawang tiwai yang } \\
\text { dikeringkan di dalam } \\
\text { ovem }\end{array}$ \\
\hline Ember & $\begin{array}{l}\text { Kapasitas } 5 \\
\text { liter }\end{array}$ & & $\begin{array}{l}\text { Untuk menyimpan } \\
\text { bawang tiwai yang } \\
\text { telah dikeringkan di } \\
\text { dalam oven }\end{array}$ \\
\hline Oven & $\begin{array}{l}\text { Dimensi: } \\
34.3 \times 39 \times \\
30.5 \mathrm{~cm}\end{array}$ & & $\begin{array}{l}\text { Alat untuk } \\
\text { mengeringkan } \\
\text { bawang tiwai yang } \\
\text { telah dirajang }\end{array}$ \\
\hline $\begin{array}{l}\text { Mesin } \\
\text { rajang }\end{array}$ & $\begin{array}{l}\text { Kapasitas: } \\
20 \text { kg/jam }\end{array}$ & & $\begin{array}{l}\text { Alat untuk merajang } \\
\text { bawang tiwai }\end{array}$ \\
\hline Sendok & $\begin{array}{l}\text { Kapasitas: } \\
1,5 \text { gram }\end{array}$ & & $\begin{array}{l}\text { Alat untuk } \\
\text { memasukkan } \\
\text { bawang tiwai ke } \\
\text { dalam kantung celup }\end{array}$ \\
\hline Alat stamp & & & $\begin{array}{l}\text { Alat stamp untuk } \\
\text { memberi tanggal } \\
\text { exp pada kotak teh } \\
\text { bawang tiwai }\end{array}$ \\
\hline $\begin{array}{l}\text { Mesin } \\
\text { sealer }\end{array}$ & $\begin{array}{l}\text { Dimension: } \\
840 \times 380 \times 5 \\
50 \mathrm{~mm} \\
\text { Speed : } 0- \\
12 \mathrm{~m} / \mathrm{Min}\end{array}$ & $\frac{10}{14}$ & $\begin{array}{l}\text { Mesing sealer } \\
\text { digunakan untuk } \\
\text { menutup kantung } \\
\text { celup dan foilpack }\end{array}$ \\
\hline
\end{tabular}


Tabel 6. Mesin dan peralatan usulan

\begin{tabular}{|c|c|c|c|}
\hline $\begin{array}{c}\text { Jenis } \\
\text { Alat }\end{array}$ & Spesifikasi & Gambar & Keterangan \\
\hline $\begin{array}{l}\text { Mesin } \\
\text { sealer } \\
\text { otomatis }\end{array}$ & $\begin{array}{l}\text { Kapasitas: } 30- \\
40 \text { pcs/menit } \\
\text { Dimensi: } 900 \\
\text { x950x1800 mm }\end{array}$ & & $\begin{array}{l}\text { Timbangan } \\
\text { untuk } \\
\text { menimbang } \\
\text { bahan di bawah } \\
1000 \text { gram }\end{array}$ \\
\hline $\begin{array}{l}\text { Mesin } \\
\text { pencuci }\end{array}$ & $\begin{array}{l}\text { Kapasitas: } 10 \\
\text { kg } \\
\text { Dimensi: } \\
900 \times 850 \times 900 \\
\text { mm }\end{array}$ & & $\begin{array}{l}\text { Mesin untuk } \\
\text { mencuci } \\
\text { bawang tiwai } \\
\text { yang telah } \\
\text { disortir }\end{array}$ \\
\hline Oven & $\begin{array}{l}\text { Dimensi: } 94 \times \\
90 \times 175 \mathrm{~cm} \\
\text { Kapasitas: } 30- \\
50 \mathrm{~kg} \\
\text { Jumlah nampan } \\
12\end{array}$ & & $\begin{array}{l}\text { Alat untuk } \\
\text { mengeringkan } \\
\text { bawang tiwai } \\
\text { yang telah } \\
\text { dirajang }\end{array}$ \\
\hline
\end{tabular}

\section{Tata letak fasilitas pabrik}

Pada umumnya tata letak pabrik yang terencana dengan baik akan ikut menentukan efisiensi dan dalam beberapa hal akan juga menjaga kelangsungan hidup ataupun kesuksesan kerja suatu industri. Selain itu pengaturan tata letak pabrik yang tepat akan dapat pula memberikan kemudahan di dalam proses supervisi serta menghadapi rencana perluasan pabrik kelak kemudian hari (Hadiguna dan Setiawan, 2008).

Sebelum pembuatan layout terlebih dahulu harus diketahui kebutuhan ruang yang akan digunakan untuk masing-masing ruangan. Penentuan tata letak pabrik yang diperlukan dilakukan dengan menggunakan metode Activity Relationship Chart (ARC), metode Activity Relationship Diagram (ARD), metode Space Relationship Diagram (SRD), dan metode Area Allocating Diagram (AAD)( Naganingrum, Jauhari \& Herdiman, L.,2013). Adapun langkah-langkah perancangan tata letak pabrik adalah sebagai berikut:

1. Langkah pertama mengidentifikasi aktivitasaktivitas yang telah didefenisikan sebagai fasilitas-fasilitas pabrik. Adapun fasilitasfasilitas yang akan dibuat dalam perancangan tata letak pabrik adalah sebagai berikut:
a. Kantor
b. Produksi
c. Pengendalian mutu
d. Penerimaan
e. Gudang bahan
f. Gudang produk jadi
g. Pengiriman
h. Pembangkit listrik
i. Penampungan limbah
j. Halaman parkir

2. Langkah kedua ialah menyiapkan lembaran Activity Relationship Chart (ARC) dan mengisinya dengan nama-nama fasilitas yang telah ditetapkan pada langkah 1 . Adapun masing-masing ruangan atau bagian pada pabrik dapat dilihat pada Tabel 7 yaitu sebagai berikut:

Tabel 7. Fasilitas Pabrik

\begin{tabular}{|c|l|}
\hline No & \multicolumn{1}{|c|}{ Ruangan atau Bagian } \\
\hline 1 & Kantor \\
\hline 2 & Produksi \\
\hline 3 & Penerimaan \\
\hline 4 & Pengendalian mutu \\
\hline 5 & Gudang bahan \\
\hline 6 & Gudang produk jadi \\
\hline 7 & Pengiriman \\
\hline 8 & Pembangkit listrik \\
\hline 9 & Penampungan limbah \\
\hline 10 & Halaman Parkir \\
\hline
\end{tabular}

3. Langkah ketiga merumuskan alasan-alasan yang dapat dijadikan dasar bahwa fasilitasfasilitas dapat didekatkan atau harus dijauhkan. Berdasarkan hasil dari data yang dibutuhkan, pabrik memerlukan 10 jenis fasilitas atau pusat kegiatan. Pusat-pusat kegiatannya adalah kantor, produksi, penerimaan, pengendalian mutu, gudang bahan, gudang produk jadi, pengiriman, pembangkit listrik, penampungan limbah, dan halaman parkir.

Pusat-pusat kegiatan sebenarnya terdiri atas unit-unit kegiatan yang lebih kecil. Namun, atas pertimbangan efisiensi penggunaan luas lantai, pada perancangan tata letak pabrik dilakukan penggabungan. Langkah awal yang dilakukan adalah menganalisis tingkat hubungan dengan menggunakan ARC. Agar proses penilaian tingkat hubungan menghasilkan penilaian yang baik, maka terlebih dahulu merumuskan alasan-alasan tingkat hubungan antar pusat kegiatan dapat dilihat pada Tabel 8 sebagai berikut:

Tabel 8. Alasan Tingkat Hubungan

\begin{tabular}{|c|l|}
\hline No & \multicolumn{1}{|c|}{ Alasan } \\
\hline 1 & Urutan aliran kerja \\
\hline 2 & Membutuhkan area yang sama \\
\hline 3 & Memudahkan pemindahan barang \\
\hline 4 & Debu dan bising \\
\hline 5 & Bau dan kotor \\
\hline
\end{tabular}


4. Memberikan penilaian berdasarkan sistem penilaian yang telah disepakati. Alasanalasan nomor 1 sampai nomor 3 menunjukkan tingkat hubungan kedekatan antar pusat kegiatan. Sebaliknya, alasanalasan nomor 4 sampai nomor 5 menunjukkan tingkat hubungan untuk dijauhkan. Berdasarkan alasan-alasan diatas, dilakukan penilaian terhadap setiap pasang fasilitas. Langkah awal pengisian ARC adalah mengidentifikasi alasan-alasan yang relevan untuk pasangan pusat kegiatan yang akan dinilai tingkat hubungannya. Hasil penilaian secara keseluruhan menggunakan Activity Relationship Chart (ARC) fasilitas pabrik dapat dilihat pada Gambar 6 sebagai berikut:

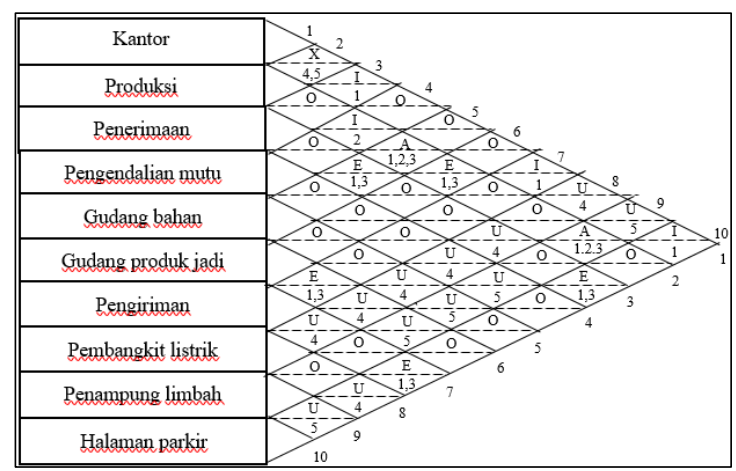

Gambar 6. Activity relationship chart (ARC)

5. Langkah kelima menyiapkan block template. Block template merupakan template yang berisi pusat kegiatan dan tingkat hubungan antarsetiap pusat kegiatan. Pada prinsipnya, block template merupakan rekapitulasi derajat kepentingan antarfasilitas yang dimasukkan dalam sebuah blok yang mewakili sebuah fasilitas. Tujuannya agar lebih mudah mengidentifikasi keterkaitan setiap fasilitas. Block template dapat dilihat pada Tabel 9.

6. Langkah keenam Pembuatan Activity Relationship Diagram (ARD) berdasarkan ARC yang telah dibuat. ARD merupakan penggambaran hubungan kedekatan antar mesin atau departemen. Berikut ini adalah Activity Relationship Diagram (ARD) dari tata letak industri pengolahan bawang tiwai menjadi produk teh celup dapat dilihat pada Gambar 7.

7. Langkah ketujuh menentukan kebutuhan luas lantai setiap pusat kegiatan atau fasilitas. Data diperoleh dari perencanaan luas lantai termasuk telah mengakomodasi kelonggaran untuk kebutuhan kelancaran kegiatan. Alat yang digunakan dalam merekapitulasi total kebutuhan luas lantai ialah total space requirement sheet.

Tabel 9. Block template

\begin{tabular}{|c|c|c|c|c|c|}
\hline A- & $\begin{array}{c}\text { O- } \\
4,5,6\end{array}$ & $\begin{array}{c}X- \\
2\end{array}$ & $\begin{array}{c}\text { A- } \\
5,9\end{array}$ & $\begin{array}{c}\text { O- } \\
3,7,8\end{array}$ & $\begin{array}{r}\text { X- } \\
1\end{array}$ \\
\hline \multicolumn{3}{|c|}{$\begin{array}{c}1 \\
\text { Kantor }\end{array}$} & \multicolumn{3}{|c|}{$\begin{array}{c}2 \\
\text { Produksi }\end{array}$} \\
\hline E- & $\begin{array}{l}\mathbf{U}- \\
8,9\end{array}$ & $\begin{array}{c}\text { I- } \\
3,7\end{array}$ & $\begin{array}{c}\text { E- } \\
6\end{array}$ & U- & $\begin{array}{l}\text { I- } \\
4\end{array}$ \\
\hline A- & $\begin{array}{c}\mathbf{O}- \\
2,4,6,7,9\end{array}$ & X- & A- & $\begin{array}{c}\text { O- } \\
1,3,5,6,7\end{array}$ & $\mathrm{X}-$ \\
\hline \multicolumn{3}{|c|}{$\begin{array}{c}3 \\
\text { Penerimaan }\end{array}$} & \multicolumn{3}{|c|}{$\begin{array}{c}4 \\
\text { Pengendalian mutu }\end{array}$} \\
\hline $\begin{array}{c}\text { E- } \\
5\end{array}$ & $\begin{array}{c}\text { U- } \\
8 \\
\end{array}$ & $\begin{array}{c}- \\
1\end{array}$ & E- & $\begin{array}{l}\text { U- } \\
8,9 \\
\end{array}$ & $\begin{array}{l}\mathbf{I}- \\
2\end{array}$ \\
\hline $\begin{array}{c}\text { A- } \\
2\end{array}$ & $\begin{array}{c}\mathbf{O}- \\
1,4,6,7 \\
\end{array}$ & $\mathrm{X}-$ & A- & $\begin{array}{c}\mathbf{O}- \\
1,3,4,5 \\
\end{array}$ & $\mathrm{X}-$ \\
\hline \multicolumn{3}{|c|}{$\begin{array}{c}5 \\
\text { Gudang bahan }\end{array}$} & \multicolumn{3}{|c|}{$\begin{array}{c}6 \\
\text { Gudang produk jadi }\end{array}$} \\
\hline $\begin{array}{c}\text { E- } \\
3\end{array}$ & $\begin{array}{l}\mathbf{U}- \\
8,9\end{array}$ & I- & $\begin{array}{l}\text { E- } \\
2,7\end{array}$ & $\begin{array}{l}\mathbf{U}- \\
8,9\end{array}$ & I- \\
\hline A- & $\begin{array}{c}\mathbf{O}- \\
2,3,4,5,9 \\
\end{array}$ & X- & A- & $\begin{array}{l}\mathbf{O}- \\
2,9\end{array}$ & X- \\
\hline \multicolumn{3}{|c|}{$\begin{array}{c}7 \\
\text { Pengiriman }\end{array}$} & \multicolumn{3}{|c|}{$\begin{array}{c}8 \\
\text { Pembangkit listrik }\end{array}$} \\
\hline $\begin{array}{c}\text { E- } \\
6\end{array}$ & $\begin{array}{l}\mathbf{U}- \\
8\end{array}$ & $\begin{array}{c}\mathbf{I}- \\
1\end{array}$ & E- & $\begin{array}{c}\mathbf{U}- \\
1,3,4,5,6, \\
7,9\end{array}$ & I- \\
\hline $\begin{array}{c}\text { A- } \\
2\end{array}$ & $\begin{array}{c}\text { O- } \\
3,7,8\end{array}$ & X- & A- & $\begin{array}{c}\mathbf{O}- \\
2,4,5,6\end{array}$ & X- \\
\hline \multicolumn{3}{|c|}{$\begin{array}{c}9 \\
\text { Penampungan limbah }\end{array}$} & \multicolumn{3}{|c|}{$\begin{array}{c}10 \\
\text { Halaman parkir }\end{array}$} \\
\hline E- & $\begin{array}{c}\mathbf{U}- \\
1,4,5,6\end{array}$ & I- & $\begin{array}{l}\mathbf{E}- \\
3,7\end{array}$ & $\begin{array}{l}\text { U- } \\
8,9\end{array}$ & $\begin{array}{c}\text { I- } \\
1\end{array}$ \\
\hline
\end{tabular}

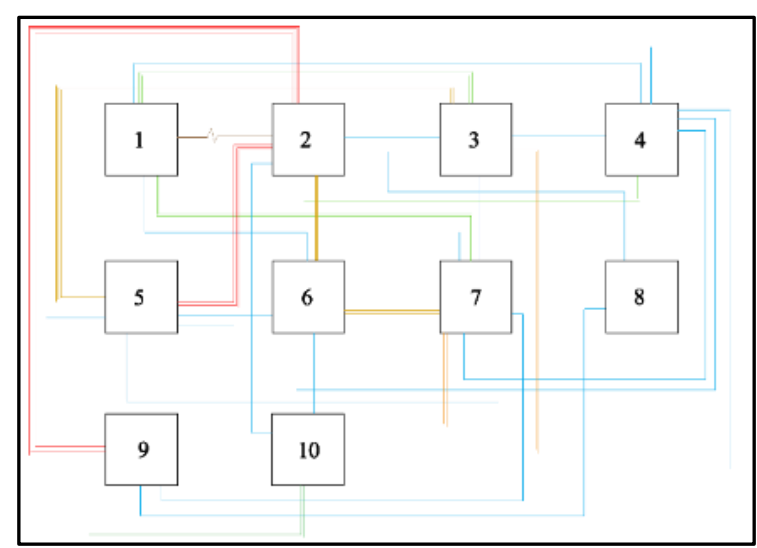

Gambar 7. Activity relationship diagram (ARD)

Kebutuhan luas lantai dalam total space requirement sheet untuk masing-masing fasilitas yang ditentukan berdasarkan lahan dari lokasi pabrik yang tersedia dan berdasarkan Neufert (2002), yaitu untuk fasilitas kantor ukuran ruang administrasi 5 x 16 dengan luas $80 \mathrm{~m}^{2}$, fasilitas produksi dengan luas $37,5 \mathrm{~m}^{2}$, fasilitas pengiriman ukuran $2,5 \times 3$ dengan luas $7,5 \mathrm{~m}^{2}$, fasilitas gudang bahan ukuran 2,5 $\times 6$ dengan luas 
$15 \mathrm{~m}^{2}$, fasilitas gudang produk jadi ukuran $2,5 \times 7$ dengan luas $17,5 \mathrm{~m}^{2}$, fasilitas penerimaan ukuran $2,5 \times 3$ dengan luas 7,5 $\mathrm{m}^{2}$, fasilitas pengendalian mutu ukuran $3 \times 4$ dengan luas $12 \mathrm{~m}^{2}$, fasilitas pembangkit listrik ukuran $2 \times 3$ dengan luas $6 \mathrm{~m}^{2}$, fasilitas penampungan limbah ukuran $2 \times 2$ dengan luas $2 \mathrm{~m}^{2}$, dan fasilitas halaman parkir ukuran $10 \times 6$ dengan luas $60 \mathrm{~m}^{2}$.

8. Langkah kedelapan melakukan gambar kasar dari layout industri pengolahan bawang tiwai menjadi produk teh celup. Gambaran kasar ini disebut juga SRD (Space Relationship Diagram). Pada SRD, mesin-mesin atau departemen-departemen dikelompokkan berdasarkan kedekatannya. Contoh pembuatan SRD pada layout industri pengolahan bawang tiwai menjadi produk teh celup dapat dilihat pada Gambar 8 yaitu sebagai berikut:

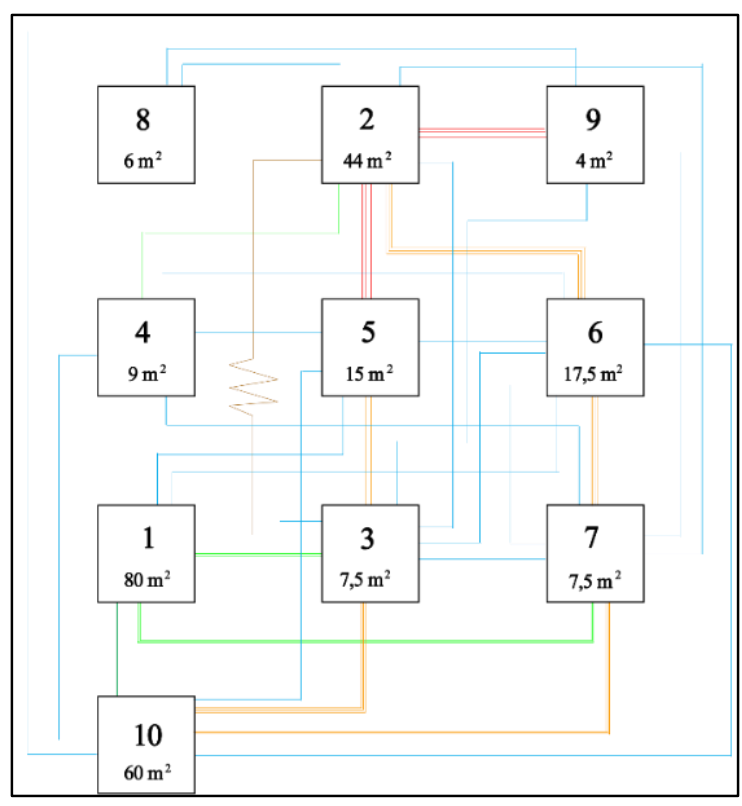

Gambar 8. Space relationship diagram (SRD)

9. Langkah kesembilan Area Allocating Diagram (AAD). Adapun Area Allocating Diagram (AAD) dapat dilihat pada Gambar 9.

10.Berdasarkan hasil layout pabrik yang dilakukan dengan menggunakan metode Activity Relationship Chart (ARC), metode Activity Relationship Diagram (ARD), metode Area Allocating Diagram (AAD), dan Space Relationship Diagram (SRD). Adapun denah tata letak pabrik dapat dilihat pada Gambar 10.

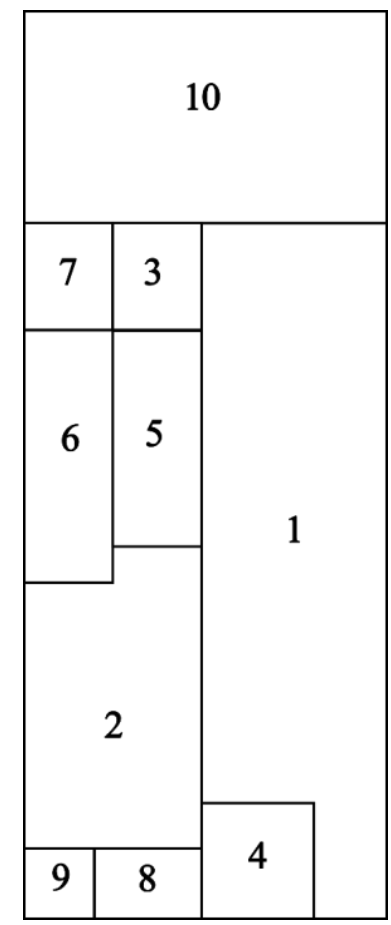

Gambar 9. Area alocating diagram (AAD)

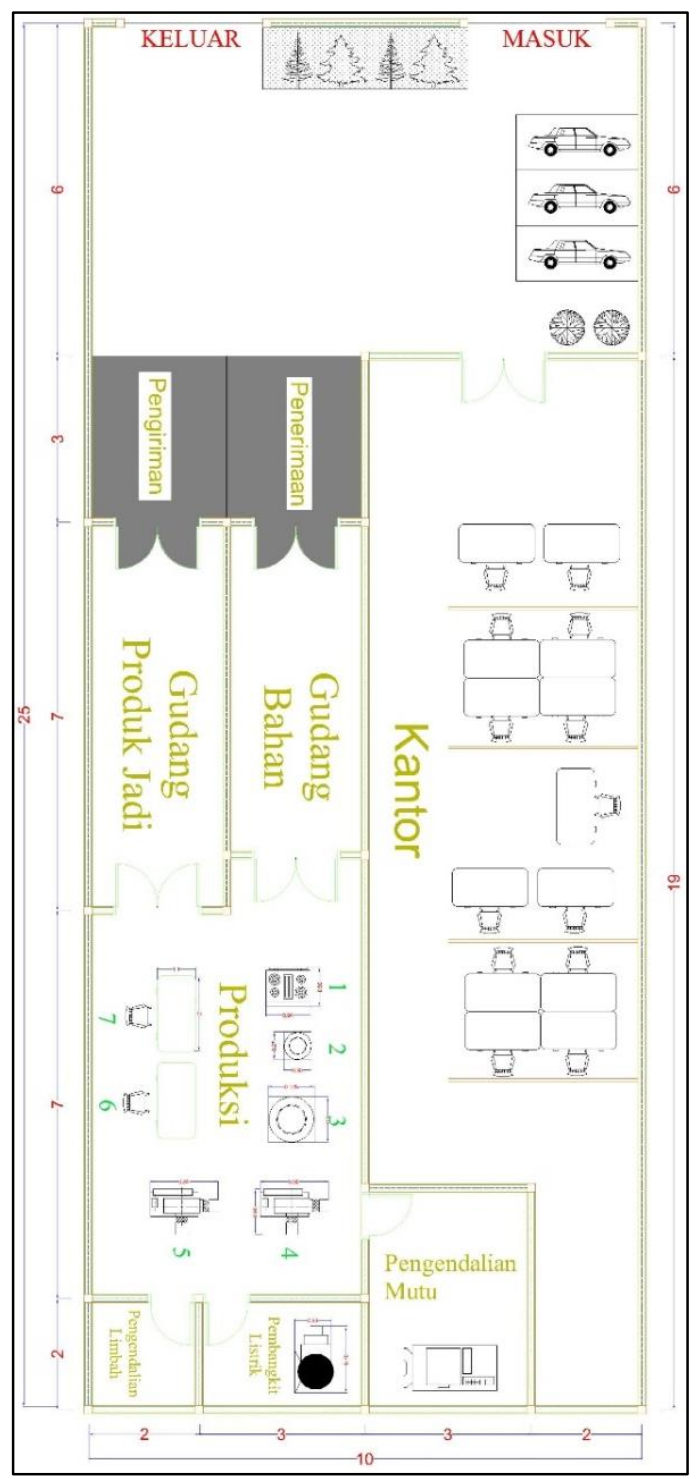

Gambar 10. Layout 


\section{Kesimpulan}

Kesimpulan yang dapat diperoleh dari pengolahan data serta analisis analisa kelayakan industri untuk pengolahan bawang tiwai menjadi produk teh celup pada UKM Solaindo adalah sebagai berikut:

1. Analisa kelayakan industri pengolahan bawang tiwai menjadi produk teh celup dari segi aspek teknis dalam penentuan lokasi usaha menggunakan metode ranking procedure hasil dari narasumber pihak UKM Solaindo dan Dinas Perindagkop dan UMKM menujukkan bahwa Tenggarong yang paling layak untuk dijadikan lokasi pendirian pabrik industri pengolahan bawang tiwai menjadi produk teh celup, karena nilai matriks penilaiannya menunjukkan hasil yang paling besar, diperoleh nilai sebesar 15,9,

2. Penentuan kapasitas produksi industri pengolahan bawang tiwai menjadi produk teh celup ini dilakukan dengan peramalan menggunakan software WinQSB. Berdasarkan hasil verifikasi tingkat kesalahan diperoleh nilai terkecil dengan menggunakan metode weighted moving average, dengan nilai MAD sebesar 92,11, nilai MSE sebesar 10.022,17, nilai MAPE sebesar 15,40, dan nilai TS sebesar -3 . Sehingga dapat disimpulkan metode weighted moving average akan menjadi acuan dalam penentuan kapasitas produksi, diperoleh nilai peramalan sebesar 7.416 unit/tahun atau $800,91 \mathrm{Kg} / \mathrm{tahun}$, jika diratarata industri pengolahan bawang tiwai menjadi produk teh celup memproduksi sebesar 618 unit/bulan atau $66,74 \mathrm{Kg} / \mathrm{bulan}$,

3. Mesin dan peralatan yang digunakan untuk proses produksi dari pabrik yang akan didirikan disetiap prosesnya yaitu loyang, mesin sealer otomatis, mesin pencuci, oven, mesin rajang, alat stamp, mesin sealer, dan

4. Penentuan layout ditentukan dengan menggunakan metode Activity Relationship Chart (ARC), Activity Relationship Diagram (ARD), Space Relationship Diagram (SRD), dan Area Allocating Diagram (AAD) dengan memiliki 9 fasilitas yakni fasilitas kantor ukuran ruang administrasi $5 \times 12$, toilet $3 \times$ 4 , dan mushola $4 \times 4$ dengan luas $88 \mathrm{~m}^{2}$, fasilitas produksi dengan luas $38 \mathrm{~m}^{2}$, fasilitas pengiriman ukuran $2 \times 6$ dengan luas $12 \mathrm{~m}^{2}$, fasilitas gudang bahan ukuran $4 \times 7$ dengan luas $28 \mathrm{~m}^{2}$, fasilitas gudang produk jadi ukuran $4 \times 5$ dengan luas $20 \mathrm{~m}^{2}$, fasilitas penerimaan ukuran $2 \times 6$ dengan luas $12 \mathrm{~m}^{2}$, fasilitas pengendalian mutu ukuran $3 \times 4$ dengan luas $12 \mathrm{~m}^{2}$, fasilitas pembangkit listrik ukuran $2 \times 4$ dengan luas $8 \mathrm{~m}^{2}$, fasilitas penampungan limbah ukuran $2 \times 2$ dengan luas $2 \mathrm{~m}^{2}$.

\section{Daftar Pustaka}

Hadiguna, R.A., dan Setiawan, H., (2008), Tata Letak Pabrik, Yogyakarta: Andi Offset.

Indrajit, R.E., dan Permono, A., (2005). Manajemen Manufaktur Tinjauan Praktis Membangun dan Mengelola Industri. Yogyakarta: Pustaka Fahima.

Kusuma, H., (2009), Manajemen Produksi Perencanaan dan Pengendalian Produksi, Yogyakarta: Andi.

Naganingrum, R.P., Jauhari, W.A., \& Herdiman, L., (2013). Perancangan Ulang Tata Letak Fasilitas di PT Komala dengan Metode Systematic Layout Planning, Performa, vol. 12, no. 1, hh. 39-50.

Neufert, E., 2002, Data Arsitek Edisi 33 Jilid 2, Jakarta: Erlangga.

Sugiyono., (2013), Metode Penelitian Kuantitatif, Kualitatif, dan R\&D. Bandung: Alfabeta.

Tohir, A. (2011). Peramalan Hasil Produksi Minyak Sawit Kasar atau Crude Palm Oil (CPO) Pada PT Kharisma Pemasaran Bersama (KPB) Nusantara di Jakarta. Skripsi. Jurusan Agribisnis Fakultas Sains dan Teknologi. Universitas Islam Negeri Syarif hidayatullah, Jakarta.

Wignjosoebroto, S., (2009), Tata Letak Pabrik dan Pemindahan Bahan Edisi Ketiga Cetakan Keempat. Surabaya: Guna Widya. 
Halaman ini sengaja dikosongkan This page is intentionally left blank 
Halaman ini sengaja dikosongkan

This page is intentionally left blank 